\title{
ZUŻYCIE ENERGII W TRANSPORCIE W KRAJACH UNII EUROPEJSKIEJ W KONTEKŚCIE IDEI ZRÓWNOWAŻONEGO ROZWOJU
}

\begin{abstract}
Zarys treści: Celem artykułu było zaprezentowanie problematyki dotyczącej sprawności funkcjonowania systemów transportowych w świetle przyjętych do realizacji w pierwszej dekadzie XXI wieku założeń europejskiej polityki transportowej. Odnotowane w ostatnich latach zmiany w modelu konsumpcji, organizacji produkcji i dostępności infrastruktury przyczyniły się do dynamicznego rozwoju systemu transportowego, co miało znaczący wpływ na poprawę konkurencyjności Europy. Podkreślono jednocześnie, że rozwój mobilności nie odbywał się z poszanowaniem zasad zrównoważonego rozwoju. Mimo nieznacznej poprawy efektywności energetycznej $\mathrm{w}$ transporcie, całkowite zużycie energii w tym sektorze wyraźnie wzrosło, co przyczyniło się do wzrostu emisji pochodzących z transportu.
\end{abstract}

Słowa kluczowe: zasoby naturalne; transport zrównoważony; emisje gazów cieplarnianych

\section{WSTĘP}

Ocena realizacji działań w zakresie budowy zrównoważonych systemów transportowych w Unii Europejskiej w ostatniej dekadzie potwierdziła, że system ten pod wieloma względami nie jest zgodny z założeniami rozwoju zrównoważonego [Motowidlak 2011, s. 341-356]. Systematyczny wzrost realizowanych zadań zarówno w zakresie przewozu towarów, jak i przewozów pasażerskich powoduje rosnące zapotrzebowanie na energię [Motowidlak 2012, s. 211-212], co prowadzi do zanieczyszczenia powietrza, zmian klimatycznych i wyczerpywania się rezerw paliw kopalnych. Transport ze względu na szczególną wrażliwość na rosnącą przepaść między globalnym popytem na ropę i jej ogra-

\footnotetext{
* Adres do korespondencji: Uniwersytet Łódzki, Instytut Ekonomik Stosowanych i Informatyki, Wydział Ekonomiczno-Socjologiczny, Zakład Logistyki, ul. Rewolucji 1905 r. nr 37/39, 90214 Łódź, e-mail: umotowidlak@ onet.eu
} 
niczoną podażą oraz konieczność redukcji emisji gazów cieplarnianych musi przejść głęboką transformację. Przekształcenie transportu na bardziej efektywny, ekologiczny, bezpieczny i niezawodny system będzie wymagało wdrożenia jednocześnie kilku wybranych działań interwencyjnych. Zrównoważona i efektywna w zakresie zużycia energii sieć mobilności wymaga stworzenia zespołu technologii niskoemisyjnych i ich rozpowszechnienia po niskich kosztach.

Celem artykułu jest przedstawienie ekologicznych uwarunkowań zmiany potrzeb energetycznych w europejskim sektorze transportu. Zaprezentowano zużycie energii w poszczególnych sektorach gospodarki w krajach Unii Europejskiej (UE). Szczególny nacisk położono na omówienie ekologicznych i ekonomicznych skutków wzrostu zapotrzebowania na energię w sektorze transportu. Dokonano analizy danych statystycznych dotyczących wielkości emisji gazów cieplarnianych (GHG) w poszczególnych sektorach w UE-27 w latach 1995-2010. W ocenie rozwoju transportu pod kątem jego zrównoważenia wykorzystano wskaźniki opracowane przez EUROSTAT. Baza wskaźników skonstruowanych przez EUROSTAT obejmuje dwa duże bloki tematyczne dotyczą zagadnień związanych z transportem. Są to: energia i środowisko oraz transport.

\section{TRANSPORT A ROZWÓJ ZRÓWNOWAŻONY}

Mobilność ma zasadnicze znaczenie dla jakości życia i dla konkurencyjności Europy. Zapewnia połączenia między poszczególnymi elementami łańcuchów dostaw. Sama w sobie stanowi ważne źródło zatrudnienia. Sieci transportowe, zwiększając możliwości wymiany handlowej, warunkują rozwój rynków krajowych oraz międzynarodowych. Mając na uwadze, że system transportowy to kompleksowa obsługa potrzeb przewozowych gospodarki i społeczeństwa danego regionu czy kraju, należy przy jego kształtowaniu brać pod uwagę wiele czynników, w tym m.in. jego wpływ na otoczenie [Zielaskiewicz, Nowak 2010, s. 21]. W ostatnich latach obserwuje się na świecie coraz większe zainteresowanie zjawiskiem zrównoważenia oraz jego implikacjami dla procesów planowania i funkcjonowania systemu transportu [Litman, Burwell 2003, s. 331]. Transport pociąga za sobą istotne gospodarczo, społecznie i środowiskowo skutki. Stanowi on ważny czynnik w odniesieniu do zjawiska zrównoważenia. Szerokie ujęcie istoty transportu zrównoważonego, uznawane za współczesną wykładnię nowego paradygmatu rozwoju w odniesieniu do sektora transportowego, określa system zrównoważonego transportu jako ten, który:

- umożliwia spełnienie podstawowej potrzeby dostępu do niego (systemu transportowego) przez jednostki i społeczeństwa w sposób bezpieczny i spójny z potrzebami zdrowia ludzkiego i ekosystemów oraz odpowiada wymogom wartości kapitałowych w obrębie danego pokolenia i w skali międzypokoleniowej; 
- jest przystępny cenowo, skutecznie funkcjonuje, oferuje wybór środków transportu oraz wspiera prężnie rozwijającą się gospodarkę;

- ogranicza emisje i odpady z uwzględnieniem możliwości planety do ich absorpcji, minimalizuje zużycie zasobów nieodnawialnych, ogranicza konsumpcję zasobów odnawialnych do poziomu zrównoważenia, przetwarza i wtórnie wykorzystuje ich komponenty oraz minimalizuje wykorzystanie gruntów, a także ogranicza natężenie hałasu [Borys 2009, s. 172].

W sektorze transportu jedną za najważniejszych form implementacji założeń rozwoju zrównoważonego jest ustalenie i przyjęcie powszechnie akceptowanych wskaźników oceny tego rozwoju. Problem pomiaru wskaźnikowego cech zrównoważenia transportu jest niezwykle trudny. W literaturze przedmiotu można znaleźć wiele różnych definicji, które w istotny sposób warunkują dobór wskaźników [Borys 2008, s. 56]. W tej różnorodności można jednak wyselekcjonować wskaźniki powtarzające się przy każdym podejściu do pomiaru postępów wprowadzania koncepcji zrównoważonego rozwoju transportu w życie. Na podstawie analizy definicji zrównoważonego rozwoju transportu oraz celów i priorytetów polityki transportowej Unii Europejskiej można zidentyfikować kluczowe cechy pomiarowe w układzie trzech sfer: społecznej, ekonomicznej i środowiskowej. Cechy te są podstawą generowania zestawów wskaźników zrównoważonego rozwoju transportu, które odgrywają ponadto szczególną rolę $\mathrm{w}$ globalnie pojmowanym procesie planowania transportu. Dostarczają one pomocnych informacji $\mathrm{w}$ procesie decyzyjnym co do wyboru i sposobu opracowania polityk, strategii i programów planistycznych.

Kształtowanie mobilności z poszanowaniem zasad zrównoważonego rozwoju, tj. mobilności wolnej od szkodliwych skutków ubocznych, racjonalnie korzystającej z zasobów naturalnych, jest od kilku lat kluczowym elementem unijnej polityki transportowej [COM(2008) 433, s. 2]. Proces rozszerzenia Unii Europejskiej (UE) przyczynił się do rozwoju powiązań handlowych, narzucając nowe podejście do funkcji i roli transportu. Transport to obok rolnictwa i przemysłu jeden z podstawowych działów gospodarki. Na sektor transportu przypada ok. 7\% unijnego PKB i ok. 5\% całkowitego zatrudnienia w UE [COM(2009) 279, s. 3]. Oddzielenie zapotrzebowania na transport od wzrostu PKB jest jednym $\mathrm{z}$ istotnych celów unijnej polityki transportowej oraz strategii zrównoważonego rozwoju. Tempo wzrostu transportu w UE jest bowiem w dużym stopniu zgodne $\mathrm{z}$ tempem wzrostu gospodarczego. Zmiany w zakresie podziału zadań przewozowych i wielkości transportu wydają się bardziej korzystne w przypadku przewozu osób niż w przypadku transportu towarowego (rys. 1). 


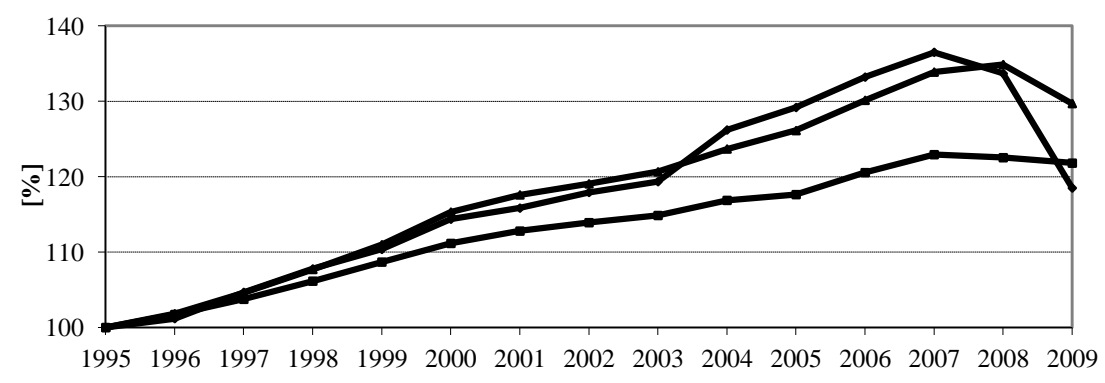

Transport towarowy $(\mathrm{tkm}) \quad$ Transport pasażerski $(\mathrm{pkm}) \quad$ PKB

Rys. 1. Rozwój transportu towarowego, pasażerskiego oraz PKB w UE-27 w latach 1995-2009 (1995 = 100, PKB wg cen z 2000 r.)

Źródło: opracowano na podstawie EU energy and transport in figures, European Commission, European Commission, Luxembourg Publications Office of the European Union, 2011.

Rozmiary przewozu osób w UE-27 ciągle wzrastają, choć w tempie wolniejszym niż stopa wzrostu PKB, co wskazuje, że w przypadku przewozu osób następuje relatywne rozdzielenie zależności pomiędzy wielkością transportu a zmianami PKB. Wzrost światowego handlu oraz coraz głębsza integracja rozszerzonej UE uniemożliwiła oddzielenie transportu towarowego od wzrostu gospodarczego. W okresie 2004-2007 wielkość przewozów towarowych wyrażonych $\mathrm{w}$ tonokilometrach wzrastała $\mathrm{w}$ stosunku rocznym $3,2 \%$, podczas gdy wzrost PKB wynosił odpowiednio 2,7\% rocznie. W 2009 spadek przewozów realizowanych przez transport towarowy zmniejszył się o $11,2 \% \mathrm{w}$ stosunku do 2008 r., podczas gdy spadek stopy PKB wynosił odpowiednio 4,2\%. Uwarunkowane było to przede wszystkim kryzysem gospodarczym, który wyraźnie dotknął sektor transportowy. Rozwój transportu towarowego uzależniony jest również od stosowanych rozwiązań w gospodarce. Czynniki, takie jak m.in. koncentracja produkcji w niewielkich ośrodkach w celu osiągnięcia ekonomii skali, dostawy „od drzwi do drzwi” lub „dokładnie na czas” przyczyniły się do silnego i trwałego popytu na transport drogowy [COM(2006) 314, s. 8].

\section{POTRZEBY ENERGETYCZNE SEKTORA TRANSPORTOWEGO I ICH SKUTKI}

Analiza wielkości i struktury przewozów, zarówno w transporcie pasażerskim, jak i towarowym, wskazują na silny rozwój sektora transportu drogowego, potwierdzając tym samym, że europejski system transportowy wciąż pod wieloma względami nie wkroczył na drogę zrównoważonego rozwoju. Całkowite zużycie energii w transporcie wzrosło między 1990 a 2010 r. o 30\%, podczas gdy w przemyśle i rolnictwie wystąpiła tendencja spadkowa (rys. 2). 


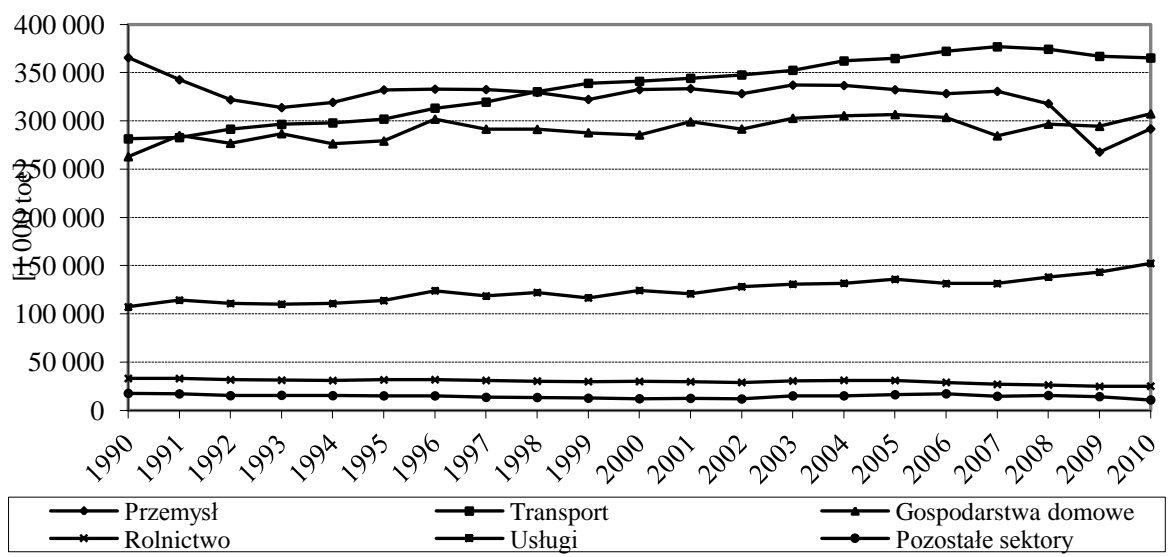

Rys. 2. Całkowite zużycie energii w poszczególnych sektorach gospodarki w UE-27 Źródło: opracowanie własne na podstawie danych EUROSTAT i Energy, Transport and Environment Indicators, European Commission, Luxembourg Office for Official Publications of the European Communities, 2011.

Ze wszystkich środków transportu lotnictwo wykazało największy wzrost, drugi pod tym względem był transport drogowy (rys. 3).

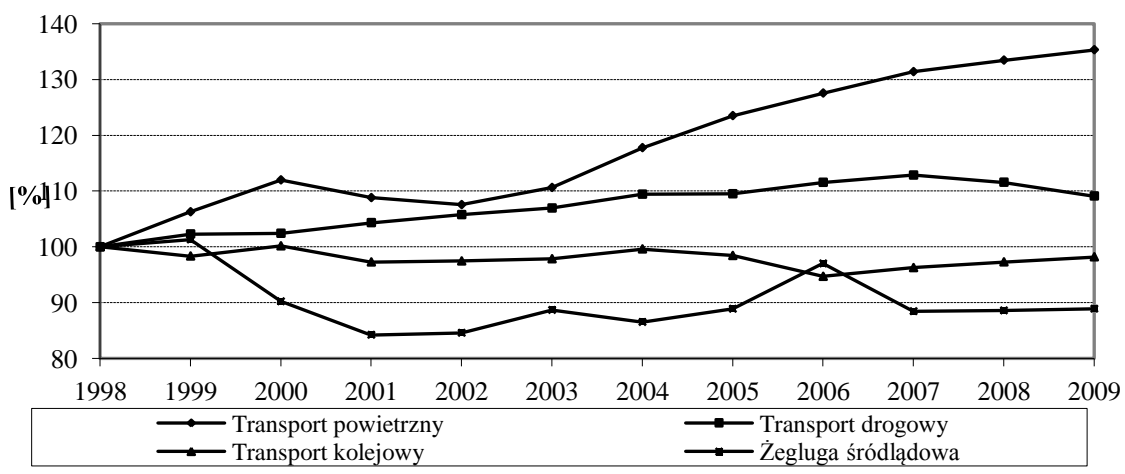

Rys. 3. Dynamika zmian zużycia energii w poszczególnych galęziach transportu w UE-27 (1998 = 100)

Źródło: opracowano na podstawie danych EUROSTAT i Energy, Transport and Environment Indicators, European Commission, Luxembourg Office for Official Publications of the European Communities, 2011.

W latach 2000-2009 zużycie energii w transporcie drogowym wzrastało średnio o $1,4 \%$ rocznie, co stanowiło niewielkie spowolnienie $\mathrm{w}$ stosunku do rocznego tempa wzrostu wynoszącego 1,7\% w latach 1990-2000. Jednak ze względu na jeszcze wyższe stopy wzrostu zużycia energii przez transport po- 
wietrzny (2,3\% rocznie), udział transportu drogowego w całkowitym zużyciu energii, przypadającym na ten sektor gospodarki, nieznacznie się zmniejszył i w 2009 r. wynosił ok. 80\%. Drugie miejsce w strukturze zużycia energii w transporcie w 2009 r. przypadło lotnictwu $(14,2 \%)$.

Rosnące zużycie energii w transporcie prowadzi do zanieczyszczenia powietrza, zmian klimatycznych i wyczerpywania się rezerw paliw kopalnych. Szczególnie ważna staje się więc poprawa efektywności energetycznej transportu opartego w większości na produktach ropy naftowej. Analiza zużycia energii w transporcie (rys. 4) w stosunku do wzrostu PKB pokazuje nieznaczne oznaki relatywnego rozdzielenia zależności między zapotrzebowaniem na energię w transporcie a wzrostem gospodarczym. Można więc stwierdzić, że efektywność energetyczna w sektorze transportu nieznacznie się poprawiła. Zyski $\mathrm{z}$ tego tytułu nie zostały jednak w całości wykorzystane do zmniejszenia całkowitego zużycia paliwa i okazały się niewystarczające, aby zrównoważyć rozwój transportu.

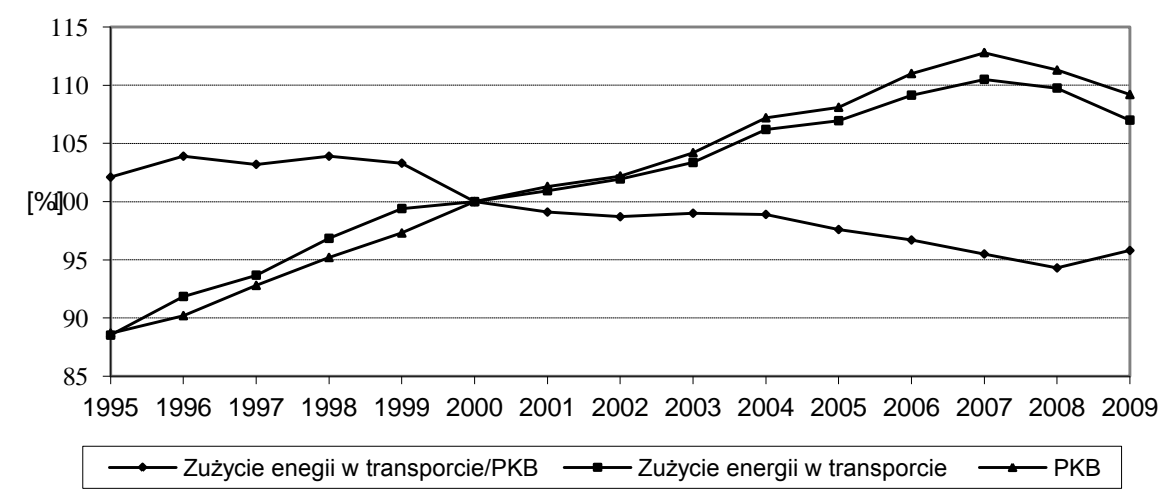

Rys. 4. Zużycie energii $w$ transporcie $w$ UE-27 $\mathrm{z}$ wylączeniem transportu morskiego i rurociągowego $(2000=100)$

Źródło: opracowano na podstawie danych EUROSTAT i Energy, Transport and Environment Indicators, European Commission, Luxembourg Office for Official Publications of the European Communities, 2011.

W obecnej sytuacji społeczno-gospodarczej zrównoważona polityka transportowa nabiera szczególnie ważnego znaczenia. Obszarem polityki, w którym należy dokonać dalszych postępów, jest ochrona środowiska naturalnego, zwłaszcza w kontekście przeciwdziałania zmianom klimatu. Główne antropogeniczne źródło emisji gazów cieplarnianych w skali globalnej stanowi spalanie paliw kopalnych, od których w 97\% uzależniony jest transport [Środowisko Europy (2010), s. 31]. Pomiary globalnych stężeń gazów cieplarnianych w atmosferze wykazują znaczący wzrost. W porównaniu z danymi z roku $1995 \mathrm{r}$., w żadnym sektorze gospodarki wzrost emisji gazów cieplarnianych nie był tak wysoki, jak w przypadku transportu. 
Dysponując danymi statystycznymi dotyczącymi wielkości emisji gazów cieplarnianych (GHG), wyrażonymi w mln ton ekwiwalentu $\mathrm{CO}_{2}$, w poszczególnych sektorach gospodarki w UE-27 w latach 1995-2010 przeprowadzono obliczenia dla liniowego modelu tendencji rozwojowej:

$Y_{t}=\alpha_{0}+\alpha_{1} T_{t}+\varepsilon_{t}$

gdzie:

$\mathrm{Y}_{\mathrm{t}}-$ całkowite GHG w mln ton ekwiwalentu $\mathrm{CO}_{2}$,

$\mathrm{T}_{\mathrm{t}}$ - zmienna czasowa przyjmująca kolejno wartości $1,2, \ldots, 16$,

$\alpha_{0}, \alpha_{1}$ - parametry strukturalne modelu,

$\varepsilon_{\mathrm{t}}$ - zmienna losowa.

Otrzymane wyniki zamieszczone zostały w tabeli 1.

Tabela 1. Oceny parametrów oraz charakterystyki statystyczne dla modelu $\mathrm{z}$ trendem

\begin{tabular}{|l|r|r|r|r|r|r|}
\hline \multicolumn{1}{|c|}{ Wyszczególnienie } & \multicolumn{1}{c|}{$\mathbf{a}_{\mathbf{0}}$} & \multicolumn{1}{c|}{$\mathbf{t}\left(\mathbf{a}_{\mathbf{0}}\right)$} & \multicolumn{1}{c|}{$\mathbf{a}_{\mathbf{1}}$} & \multicolumn{1}{c|}{$\mathbf{t}\left(\mathbf{a}_{\mathbf{1}}\right)$} & \multicolumn{1}{c|}{$\mathbf{S e}$} & \multicolumn{1}{c|}{$\mathbf{R}^{\mathbf{2}}$} \\
\hline Przemysł & 1191,60 & 69,95 & $-11,86$ & 5,93 & 30,17 & 0,746 \\
Transport & 850,02 & 101,46 & 10,55 & 10,72 & 14,84 & 0,906 \\
Gospodarstwa domowe & 544,49 & 39,93 & $-7,15$ & 4,47 & 24,15 & 0,624 \\
Rolnictwo & 92,01 & 103,36 & $-1,32$ & 12,59 & 1,58 & 0,930 \\
Usługi & 192,58 & 34,51 & $-1,30$ & 1,99 & 9,89 & 0,248 \\
Pozostałe sektory & 2366,88 & 137,15 & $-4,52$ & 2,23 & 30,57 & 0,293 \\
Ogółem & 5237,59 & 136,27 & $-15,61$ & 3,46 & 68,09 & 0,499 \\
\hline
\end{tabular}

Źródło: Obliczenia własne.

$\mathrm{Z}$ rezultatów zamieszczonych $\mathrm{w}$ tabeli 1 wynika, że w przemyśle, gospodarstwach domowych, rolnictwie, usługach oraz $\mathrm{w}$ pozostałych sektorach występował systematyczny spadek emisji GHG, ponieważ oceny $\mathrm{a}_{1}$ dla wymienionych sektorów są ujemne. Oceny te, z wyjątkiem oceny dla sektora usług, są statystycznie istotne. Jedynie dla sektora transportu odnotowano systematyczny wzrost emisji GHG, wynoszący 10,55 mln ton ekwiwalentu $\mathrm{CO}_{2}$ rocznie. Dla tego sektora uzyskano też najwyższą wartość współczynnika determinacji $\mathrm{R}^{2}=$ 0,906. Największy spadek emisji GHG wystąpił w przemyśle i wynosił 11,86 mln ton ekwiwalentu $\mathrm{CO}_{2}$, następnie w gospodarstwach domowych $(7,15 \mathrm{mln}$ ton ekwiwalentu $\left.\mathrm{CO}_{2}\right)$, w pozostałych sektorach $(4,52 \mathrm{mln}$ ton ekwiwalentu $\left.\mathrm{CO}_{2}\right)$, w rolnictwie $\left(1,32 \mathrm{mln}\right.$ ton ekwiwalentu $\left.\mathrm{CO}_{2}\right)$ oraz w sektorze usług $(1,30$ mln ton $\mathrm{CO}_{2}$ ). Spadek emisji GHG we wspomnianych sektorach dał łączny efekt dla emisji GHG wynoszący 15,61 mln ton ekwiwalentu $\mathrm{CO}_{2}$ rocznie. Należy podkreślić, że największą regularność spadku emisji GHG wykazywał sektor rolnictwa, dla którego współczynnik determinacji $\mathrm{R}^{2}=0,930$ jest największy. Natomiast najmniej regularny spadek emisji GHG występował 
w sektorze usług, dla którego współczynnik determinacji $\mathrm{R}^{2}$ wynosił tylko 0,248 .

Przedmiotem analizy była również wielkość emitowanych GHG (w mln ton ekwiwalentu $\mathrm{CO}_{2}$ ) przez poszczególne gałęzie transportu w UE-27 w latach 1995-2010, na podstawie których przeprowadzono obliczenia z wykorzystaniem liniowego modelu tendencji rozwojowej. Wyniki obliczeń uzyskane dla tego modelu przedstawione zostały w tabeli 2 .

Tabela 2. Oceny parametrów oraz charakterystyki statystyczne dla modelu $z$ trendem

\begin{tabular}{|l|r|r|r|r|r|r|}
\hline Wyszczególnienie & \multicolumn{1}{c|}{$\mathbf{a}_{\mathbf{0}}$} & $\mathbf{t}\left(\mathbf{a}_{\mathbf{0}}\right)$ & \multicolumn{1}{c|}{$\mathbf{a}_{\mathbf{1}}$} & \multicolumn{1}{c|}{$\mathbf{t}\left(\mathbf{a}_{\mathbf{1}}\right)$} & \multicolumn{1}{c|}{$\mathbf{S e}$} & $\mathbf{R}^{\mathbf{2}}$ \\
\hline Transport drogowy & 786,55 & 129,07 & 11,48 & 14,95 & 10,36 & 0,953 \\
Transport kolejowy & 10,83 & 84,22 & $-0,20$ & 12,21 & 0,22 & 0,931 \\
Transport lotniczy & 99,02 & 37,22 & 4,70 & 14,02 & 4,52 & 0,947 \\
Żegluga śródlądowa & 18,58 & 29,58 & 0,22 & 2,73 & 1,07 & 0,403 \\
Ogółem & 030,28 & 164,25 & 21,43 & 27,11 & 10,66 & 0,985 \\
\hline
\end{tabular}

Źródło: Obliczenia własne.

$\mathrm{Z}$ rezultatów zamieszczonych w tabeli 2 wynika, że dla transportu drogowego, lotniczego, żeglugi śródlądowej, a także dla emisji GHG ogółem występował systematyczny wzrost w badanym okresie. Świadczą o tym dodatnie oceny $a_{1}$ parametru $\alpha_{1}$. Oceny te są statystycznie istotne. Wysokie są również wartości (z wyjątkiem żeglugi śródlądowej) współczynników determinacji $\mathrm{R}^{2}$, które zawierają się $\mathrm{w}$ granicach od 0,947 (dla transportu lotniczego) do 0,953 (dla transportu drogowego) oraz do 0,985 dla emisji GHG ogółem. Największy przyrost, co jest zrozumiałe, zaobserwowano dla emisji ogółem, wynosił on $21,43 \mathrm{mln}$ ton rocznie.

Największy wpływ na wzrost emisji GHG ogółem miał transport drogowy $\left(11,48\right.$ mln ton ekwiwalentu $\left.\mathrm{CO}_{2}\right)$ i transport lotniczy $(4,70$ mln ton ekwiwalentu $\mathrm{CO}_{2}$ ), znacznie zaś mniejszy żegluga śródlądowa, bo tylko $0,22 \mathrm{mln}$ ton ekwiwalentu $\mathrm{CO}_{2}$ rocznie. Zmniejszającą się systematycznie emisję GHG odnotowano jedynie dla transportu kolejowego. Spadek ten wynosił 0,20 mln ton ekwiwalentu $\mathrm{CO}_{2}$ rocznie. Oceny $\mathrm{a}_{0} \mathrm{i} \mathrm{a}_{1}$ są $\mathrm{w}$ tym przypadku statystycznie istotne. Uzyskano także wysoki stopień zgodności rezultatów teoretycznych z danymi empirycznymi. Świadczy o tym wysoka wartość współczynnika determinacji, która wynosi 0,931 . Potwierdza to także niska wartość standardowego odchylenia reszt, która w tym przypadku wynosi $0,22 \mathrm{mln}$ ton ekwiwalentu $\mathrm{CO}_{2}$.

Na podstawie danych obrazujących poziom emisji GHG, wyrażony w mln ton ekwiwalentu $\mathrm{CO}_{2}$, oraz zużycie energii, wyrażone w 1000 toe w poszcze- 
gólnych sektorach gospodarki, w UE-27 przyjęto weryfikację hipotezy dotyczącej związku między GHG a całkowitym zużyciem energii w latach 1995-2010.

Do weryfikacji tej hipotezy wykorzystano następujący model:

$Y_{t}=\alpha_{0}+\alpha_{1} X_{t}+\varepsilon_{t}$

gdzie:

$\mathrm{Y}_{\mathrm{t}}$ - emisja GHG w mln ton w roku $\mathrm{t}$,

$\mathrm{X}_{\mathrm{t}}$ - całkowite zużycie energii (1000 toe) w roku t,

$\alpha_{0}, \alpha_{1}$ - parametry strukturalne modelu,

$\varepsilon_{\mathrm{t}}$ - zmienna losowa.

Zastosowanie modelu przyczynowo-skutkowego pozwoliło na uzyskanie rezultatów, które zamieszczone zostały w tabeli 3.

Tabela 3. Oceny parametrów oraz charakterystyki statystyczne dla modelu przyczynowo-skutkowego

\begin{tabular}{|l|r|r|r|l|r|r|}
\hline \multicolumn{1}{|c|}{ Wyszczególnienie } & \multicolumn{1}{c|}{$\mathbf{a}_{\mathbf{0}}$} & \multicolumn{1}{c|}{$\mathbf{t}\left(\mathbf{a}_{\mathbf{0}}\right)$} & \multicolumn{1}{c|}{$\mathbf{a}_{\mathbf{1}}$} & \multicolumn{1}{c|}{$\mathbf{t}\left(\mathbf{a}_{\mathbf{1}}\right)$} & \multicolumn{1}{c|}{$\mathbf{S e}$} & \multicolumn{1}{c|}{$\mathbf{R}^{\mathbf{2}}$} \\
\hline Przemysł & $-340,40$ & 0,35 & 0,0040 & 1,48 & 55,00 & 0,155 \\
\hline Transport & 257,24 & 6,92 & 0,0020 & 18,12 & 9,06 & 0,965 \\
\hline Gospodarstwa domowe & 285,00 & 0,78 & 0,0007 & 0,56 & 38,91 & 0,026 \\
\hline Rolnictwo & $-6,00$ & 0,36 & 0,0029 & 5,30 & 3,25 & 0,701 \\
\hline Usługi & 242,42 & 4,73 & $-0,0005$ & 1,16 & 10,80 & 0,101 \\
\hline Pozostałe sektory & 2250,49 & 26,47 & 0,0058 & 0,98 & 35,01 & 0,073 \\
\hline Ogółem & 6339,40 & 7,91 & $-0,0011$ & 1,52 & 88,09 & 0,162 \\
\hline
\end{tabular}

Zródło: Obliczenia własne.

Istotne statystycznie oceny $\mathrm{a}_{0} \mathrm{i}_{\mathrm{a}}$ uzyskano tylko dla transportu. Ocena $\mathrm{a}_{1}$ informuje w tym przypadku o systematycznym wzroście emisji GHG wynoszącym rocznie $0,0020 \mathrm{mln}$ ton, wywołanym zmianą całkowitego zużycia energii o jedną jednostkę (1000 toe). Uzyskano w tym przypadku wysoką wartość współczynnika determinacji $\mathrm{R}^{2}=0,965$. Wartości statystyk sprawdzianu t-Studenta wielokrotnie przekraczają wartość krytyczną wynoszącą 2,18. Istotną statystycznie ocenę $a_{1}$ uzyskano także dla rolnictwa. Dość wysoki jest także współczynnik determinacji $\mathrm{R}^{2}=0,701$. Istotne statystycznie oceny $\mathrm{a}_{0}$ uzyskano dla pozostałych sektorów oraz dla emisji GHG, ogółem jednak wartości współczynników determinacji $\mathrm{R}^{2}$ są bardzo niskie i wynoszą odpowiednio 0,073 i 0,162 . Na podstawie uzyskanych wyników można więc stwierdzić, że dla przemysłu, gospodarstw domowych, usług, pozostałych sektorów, a także dla emisji ogółem nie ma związku przyczynowo-skutkowego między badanymi zmiennymi. 


\section{POLITYKA TRANSPORTOWA WOBEC WSPÓŁCZESNYCH WYZWAŃ}

Realizacja celów unijnej strategii zrównoważonego rozwoju i zmniejszenie negatywnego wpływu transportu $\mathrm{w}$ wymiarze społecznym i środowiskowym stanowi wyzwanie do podjęcia zdecydowanych działań w kierunku zintegrowanego, zaawansowanego technologicznie i przyjaznego użytkownikowi systemu.

Tendencje światowe, implikujące działania w ramach polityki transportowej UE, to przede wszystkim:

- malejąca dostępność paliw transportowych,

- geopolityczne uwarunkowania rozmieszczenia zasobów paliw transportowych,

- globalizacja produkcji i związanych z nią łańcuchów dostaw,

- wzrost gospodarczy i zmiany demograficzne,

- strategie przedsiębiorstw wobec zmian popytu i oczekiwań klientów.

Obecne tendencje oraz konieczność przejścia na gospodarkę niskoemisyjną, a także rosnące obawy co do bezpieczeństwa dostaw energii spowodują większy udział energii ze źródeł odnawialnych, której koszty wytwarzania spadną dzięki postępowi technicznemu i masowej produkcji. W nadchodzących dziesięcioleciach oczekiwany jest dalszy wzrost cen ropy i innych paliw kopalnych, ze względu na zwiększający się popyt i wyczerpywanie się tańszych w eksploatacji źródeł wydobycia [COM(2009) 279, s. 6]. Przejście na ceny relatywne podniesie atrakcyjność inwestowania w alternatywne źródła energii. Najpilniejszymi priorytetami są:

- lepsza integracja różnych rodzajów transportu jako droga do poprawy ogólnej efektywności systemu,

- stosowanie paliw alternatywnych,

- poprawa efektywności energetycznej pojazdów,

- działania z zakresu logistyki transportu,

- rozwój infrastruktury transportowej,

- proekologiczna polityka podatkowa [COM(2011) 144, s. 27-31].

\section{PODSUMOWANIE}

Transport należy do sektorów gospodarki o zasadniczym znaczeniu dla utrzymania i zwiększenia europejskiej konkurencyjności. System transportu zapewnia wysoki poziom mobilności w Europie, wraz z ciągle rosnącą efektywnością w zakresie szybkości, komfortu, bezpieczeństwa i dogodności.

Na podstawie przeprowadzonej analizy w odniesieniu do rozwoju transportu w minionej dekadzie można stwierdzić, że działalność tego sektora uległa znacznemu rozwojowi, któremu nie towarzyszyły odpowiednie postępy w zakresie ograniczenia zużycia energii i redukcji emisji gazów cieplarnianych. Nadal jest on w ponad 95\% zależny od paliw kopalnych, co ma negatywne 
skutki dla bezpieczeństwa dostaw energii oraz zmian klimatu. Zwiększający się popyt na nieodnawialne źródła energii, wyczerpywanie się tańszych w eksploatacji źródeł ich wydobycia oraz pogarszający się stan środowiska naturalnego wymuszają konieczność przejścia na niskoemisyjny system transportowy.

\title{
LITERATURA
}

Borys T., (2008), Analiza istniejacych danych statystycznych pod kątem ich użyteczności dla określenia poziomu zrównoważonego transportu wraz z propozycja ich rozszerzenia. Raport $z$ realizacji pracy badawczej, Ministerstwo Infrastruktury, Jelenia Góra-Warszawa.

Borys T., (2009), Pomiar zrównoważonego rozwoju transportu, [w:] D. Kiełczewski, B. Dobrzyńska (red.), Ekologiczne problemy zrównoważonego rozwoju, Wyd. Wyższej Szkoły Ekonomicznej w Białymstoku, Białystok.

COM (2006) 314, Utrzymać Europę w ruchu-zrównoważona mobilność dla naszego kontynentu. Przegląd średniookresowy Białej księgi Komisji Europejskiej dotyczacej transportu z 2001 r., Bruksela.

COM (2008) 433, Ekologiczny transport, Komisja Wspólnot Europejskich, Bruksela.

COM (2009) 279, Zrównoważona przyszłość transportu: w kierunku zintegrowanego, zaawansowanego technologicznie i przyjaznego użytkownikowi systemu, Bruksela.

COM (2011) 144, Plan utworzenia jednolitego europejskiego obszaru transportu - dążenie do osiagnięcia konkurencyjnego i zasobooszczędnego systemu transportu, Bruksela.

Energy, (2011), Transport and Environment Indicators, European Commission, Luxembourg Office for Official Publications of the European Communities.

EU energy and transport in figures, European Commission, Luxembourg Publications Office of the European Union, (2011).

Litman T., Burwell D., (2003), Issues in Sustainable Transportation, „International Journal of Global Environmental Issues", Vol. 6, No. 4. DOI: http://dx.doi.org/10.1504\% 2FIJGENVI.2006.010889

Motowidlak U., (2011), Polityka transportowa a rozwój zrównoważony, [w:] D. Kiełczewski (red.), Implementacyjne aspekty wdrażania zrównoważonego rozwoju, Wydawnictwo Wyższej Szkoły Ekonomicznej w Białymstoku, Białystok. 2011.

Motowidlak U., (2012), Wybrane aspekty transportu zrównoważonego, „Logistyka”, $\mathrm{nr} 2$.

Środowisko Europy. Stan i prognozy. Synteza, (2010), Europejska Agencja Środowiska, Kopenhaga.

Zielaskiewicz H., Nowak I., (2010), Kształtowanie sieci transportowej z uwzględnieniem zasad internalizacji, „Logistyka”, nr 1.

\section{USE OF NATURAL RESOURCES IN TRANSPORT}

\begin{abstract}
The purpose of this article was to present problems concerning efficiency of transport systems in comparison with aims of European transport systems which should be conducted till I decade of XXI century. The changes in consumption models, organizations of production and accessibility to infrastructure which were recently recorded had led to rapid development of transport systems. It had a great influence on improvement of competitiveness in Europe. It was pointed out that the development of mobility did not abide by the principles of sustainable development. Although there was a marginal improvement of energetic efficiency in transport, the total use of energy considerably increased. This contributed to rise of emissions which were produced by transport.
\end{abstract}

Keywords: natural resources; sustainable transport; greenhouse gas emissions. 